\title{
Pharmacological properties of fireweed (Epilobium angustifolium L.) and bioavailability of ellagitannins. A review
}

\author{
MARIOLA DREGER ${ }^{1 *}$, ARTUR ADAMCZAK², KATARZYNA SEIDLER-ŁOŻYKOWSKA², KAROLINA \\ WIELGUS ${ }^{1}$
}

${ }^{1}$ Department of Biotechnology

Institute of Natural Fibres and Medicinal Plants

Wojska Polskiego 71B

60-630 Poznań, Poland

${ }^{2}$ Department of Botany, Breeding and Agricultural Technology of Medicinal Plants Institute of Natural Fibres and Medicinal Plants

Kolejowa 2

62-064 Plewiska, Poland

*corresponding author: phone +48 (61) 8455 819, e-mail: mariola.dreger@iwnirz.pl

\section{Summary}

Fireweed (Epilobium angustifolium L.) is a well-known medicinal plant traditionally used in the treatment of urogenital diseases, stomach and liver disorders, skin problems, etc. E. angustifolium extracts show antiandrogenic, antiproliferative, cytotoxic, antioxidant, anti-inflammatory, immunomodulatory, and antimicrobial activities. The unique combination of biological properties demonstrated by the results of some studies indicates that fireweed has a positive effect in benign prostatic hyperplasia (BPH) and potentially in the prostate cancer chemoprevention. However, the efficacy of E. angustifolium phytotherapy is still poorly tested in clinical trials, while numerous beneficial effects of extracts have been documented in the in vitro and in vivo tests. Fireweed is rich in polyphenolic compounds, particularly ellagitannins. Currently, polyphenols are considered to be modulators of beneficial gut microbiota. The literature data support the use of ellagitannins in the prostate cancer chemoprevention, but caution is advised due to the highly variable production of urolithins by the individual microbiota. A better understanding of the microbiota's role and the mechanisms of its action are crucial for an optimal therapeutic effect. This paper aims to summarize and discuss experimental data concerning pharmacological properties of E. angustifolium and bioavailability of ellagitannins - important bioactive compounds of this plant.

Key words: rosebay willowherb, pharmacology, bioavailability, benign prostatic hyperplasia (BPH), oenothein B, urolithins, gut microbiota 
Słowa kluczowe: wierzbówka kiprzyca, farmakologia, biodostępność, tagodny rozrost prostaty (BPH), oenoteina $B$, urolityny, mikroflora jelitowa

\section{INTRODUCTION}

Fireweed (Epilobium angustifolium L., syn. Chamerion angustifolium /L./ Holub) is a medicinal plant from the Onagraceae family traditionally used in the treatment of urogenital diseases, stomach disorders, liver inflammation, burns, wounds, and skin problems [1]. This species has an abundance of polyphenolic compounds, especially ellagitannins, and also phenolic acids and flavonoids. Among other bioactive constituents of fireweed, sterols, triterpenes, fatty acids, and essential oils have been found. The therapeutic effects of E. angustifolium include antiandrogenic, antiproliferative, cytotoxic, antioxidant, anti-inflammatory, immunomodulatory, and antimicrobial activities (fig. 1) [1]. The European Medicines Agency Assessment Report [2] on E. angustifolium and E. parviflorum concludes that the aerial parts of these herbs are useful in alleviating symptoms of lower urinary tracks related to benign prostatic hyperplasia (BPH) and assumes their safety in this respect.

$\mathrm{BPH}$ is an age-related disease which develops after the age of 40 and among the 60-year-old men it affects more than $50 \%$ [3]. BPH is mainly caused by changes in hormone balance and cell-growth factors in the prostate gland. Androgen deficiency condition occurring in elderly men as well as previous inflammation of the prostate gland and positive family history are the risk factors contributing to $\mathrm{BPH}$ development and progression. Although the molecular mechanism of BPH development is still not fully understood, the common accepted theory postulates the key role of enzymes: steroid $5 \alpha$-reductase $(5 \alpha-\mathrm{R})$ and aromatase $(5 \alpha-\mathrm{A})$ and growth factors in this process [4]. The $5 \alpha-\mathrm{R}$ transforms testosterone into dihydrotestosterone (DHT) in prostate cells. DHT binds androgen receptors with a higher affinity than testosterone and it directly stimulates the growth and differentiation of prostate cells. Binding to androgen receptors triggers a transduction cascade of growth factors (epidermal growth factors - EGF, insulin-like growth factors - IGF and others) leading to abnormal prostate cell proliferation. Estrogens act synergistically with androgens and promote the development of $\mathrm{BPH}$. Increased expression of the $5 \alpha$-A that catalases the conversion of androgens into estrogens was observed in hypertrophic prostates [4].

$\mathrm{BPH}$ is a good target for preventive phytotherapy due to the long latency of this disease, and it is usually well tolerated by patients. It is also a cost-effective alternative. The effectiveness of phytotherapy in the $\mathrm{BPH}$ prevention is still being discussed, mainly due to limited double-blind clinical trials or difficulties associated with different extraction and formulation methods, variability in the chemical composition and the lack of raw material standardization. Currently, there are no clinical studies regarding the effectiveness of E. angustifolium, although a number of preclinical trials have revealed the anti-proliferative, anti-inflammatory, analgesic, antioxidant and antimicrobial effects of its extracts [5].

Various beneficial effects of fireweed have been attributed to the phenolic compounds, particularly to macrocyclic ellagitannin - oenothein $B[1,6,7]$. The opinion that the regular consumption of ellagitannin-rich products can help reduce the risk of some chronic diseases, and may be useful in the cancer prevention is commonly accepted $[8,9]$. Bioavailability of ellagitannins is poorly understood, but it has been intensively studied since last decade. The gastrointestinal microbiota is an important modulator and contributor to human health, and it is involved in the management of host metabolism of polyphenols, including ellagitannins. Nowadays, the ecology of gut microbiota and its health benefits are hot topics in research on metabolic syndrome, obesity-related diseases, inflammatory bowel disease and other conditions $[10,11]$. According to the new concept of prebiotics, polyphenols are modulators of beneficial microbiota and therefore great hopes are associated with their use in the prevention of cancer as well as metabolic or cardiovascular diseases.

The aim of the present work was to summarize and discuss the current literature data concerning pharmacological properties of E. angustifolium and bioavailability of ellagitannins - important bioactive compounds of this species. This overview is a continuation of our prior article on botany, phytochemistry and traditional uses of fireweed [1]. 


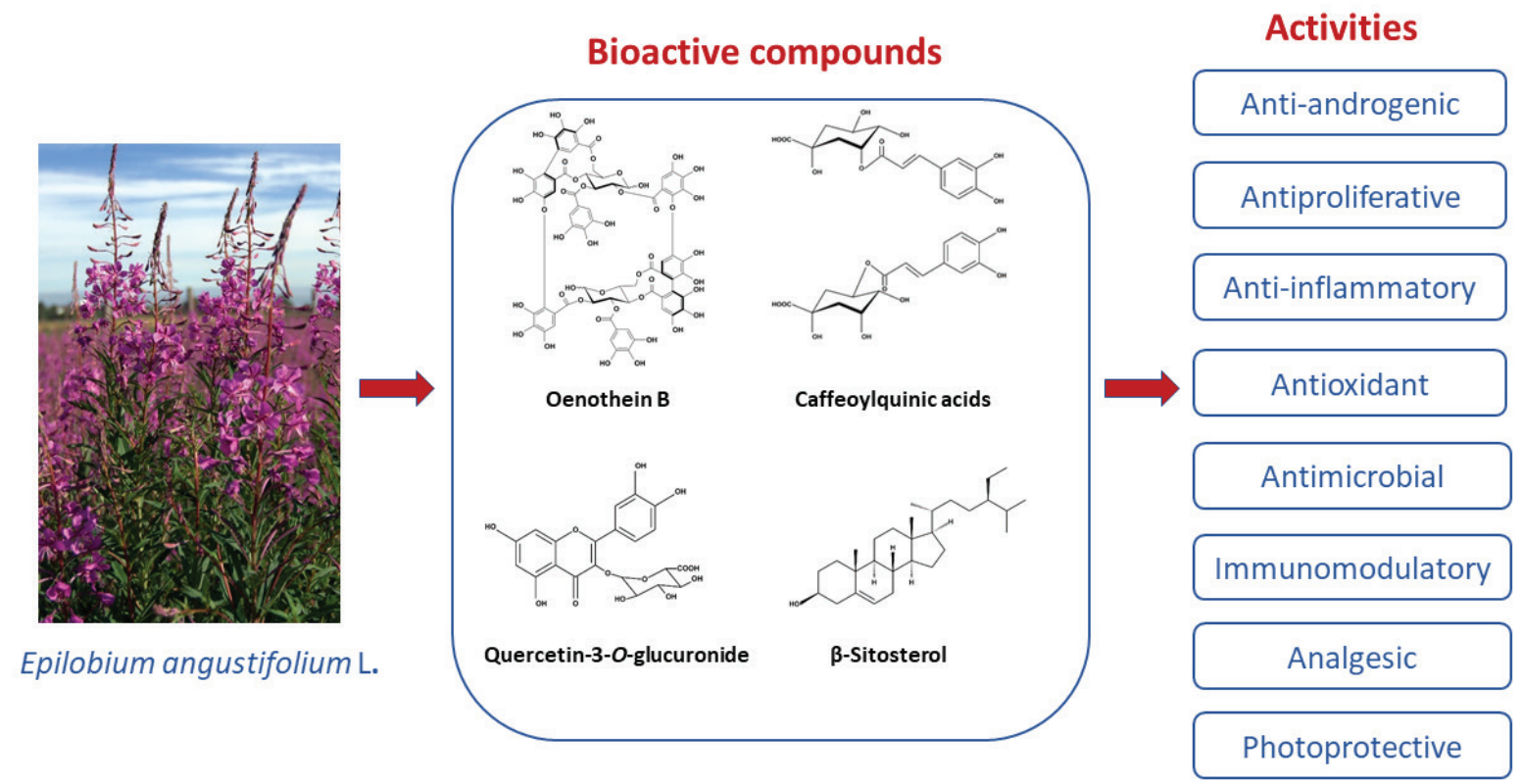

Figure 1

Pharmacological properties of Epilobium angustifolium

\section{PHARMACOLOGICAL PROPERTIES}

\section{Anti-androgenic activity}

The anti-androgenic effect of $E$. angustifolium extract was confirmed in animal tests [12] (tab. 1). Orally administered water extract (dose: $40 \mathrm{mg} / \mathrm{kg} \mathrm{bw}$ ) decreased the weight of vesicles in intact rats, whereas in castrated and testosterone-stimulated rats an increase in prostate vesicle weight was observed (pro-androgenic effect). Although the mechanism of action was not ascertained, it was suggested that the extract contains compounds which enhances bioactivity of the applied androgens. The inhibitory activity of oenothein A and B against $5 \alpha$-reductase and aromatase has been reported in other studies $[13,14]$. More recent work reported antiproliferative and anti-androgen activities of $E$. angustifoli$u m$ water extract and oenothein B in in vitro and in vivo models [15]. Oral supplementation of rats implanted with LNCaP cells with extract (dose: $50-200 \mathrm{mg} / \mathrm{kg} \mathrm{bw}$ ) resulted in a significant reduction of prostatic adenoma by up to $13 \%$. Recently, anti-androgenic effect of $n$-butanol extract against testosterone propionate-induced $\mathrm{BPH}$ rats via down-regulation of androgen level and the suppression of NF- $\kappa \mathrm{B}$ (nuclear transcription factor kappa B) expression has been reported [16]. The decreased level of dihydrotestosterone and activity of aromatase in a dose-dependent manner was demonstrated after oral administration of extract (100-400 mg/kg bw). The therapeutic effect was similar to finasteride treated group ( $3 \mathrm{mg} / \mathrm{kg}$ b.w). Gallic acid and avicularin (quercetin 3-O- $\alpha$-L-arabinofuranoside) were the most active compounds in the inhibition of prostate specific antigen (PSA) secretion with the level of 21.82 and $33.19 \%$, respectively.

\section{Antiproliferative and cytotoxic activities}

E. angustifolium extracts showed antiproliferative activities towards different cell lines, including human prostate epithelial cells (PZ-HPV-7 line), human astrocytoma cells (1321N1), human prostate adenocarcinoma cells (LNCaP), and normal mammary cells (HMEC) $[17,18]$ (tab. 1). The antiproliferative effect was not specific to prostate cells and the inhibition was similar (in $\mathrm{IC}_{50}$ value) for both androgen-sensitive (LNCaP) and androgen nonresponsive cells (PZ-HPV-7). The above-mentioned effect was attributed to the high amount of oenothein B in ethanolic extract. The ability of E. angustifolium extracts to induce metallopeptidase activity in a PC-3 cell model (androgen-independent prostate cancer line) was also documented [19-21].

Stolarczyk et al. [22] demonstrated the inhibition 
Table 1.

Literature overview on the main biological activities of Epilobium angustifolium extracts

\begin{tabular}{|c|c|c|c|}
\hline $\begin{array}{l}\text { Plant material/extracts/ } \\
\text { compounds }\end{array}$ & Experimental model/assays & Effect & Reference \\
\hline $\begin{array}{l}\text { E. angustifolium herb/ } \\
\text { aqueous and hexane } \\
\text { extracts }\end{array}$ & $\begin{array}{l}\text { In vivo; anti-androgen assay on intact and testosterone } \\
\text { stimulated castrated rats }\end{array}$ & $\begin{array}{l}\text { Anti-androgenic effect of aqueous } \\
\text { extract }(40 \mathrm{mg} / \mathrm{kg} / \text { day }) \text { on intact rats }\end{array}$ & [12] \\
\hline $\begin{array}{l}\text { E. angustifolium/aqueous } \\
\text { extract }\end{array}$ & $\begin{array}{l}\text { In vitro; LNCaP, PZ-HPV-7 and Du } 145 \text { (human prostate } \\
\text { carcinoma cells). In vivo; male rats implanted with LNCaP cells }\end{array}$ & $\begin{array}{l}\text { Anti-androgenic and selective anti- } \\
\text { proliferative effect of extract and } \\
\text { oenothein B }\end{array}$ & {$[15]$} \\
\hline $\begin{array}{l}\text { E. angustifolium leaves, } \\
\text { stems, flowers/ethyl } \\
\text { acetate and } n \text {-butanol } \\
\text { extracts }\end{array}$ & $\begin{array}{l}\text { In vivo; testosterone propionate stimulated castrated rats. In } \\
\text { vitro; human prostate cells (BPH-1 and LNCaP lines); cell } \\
\text { proliferation (MTT assay) and cytotoxicity assay; PSA (prostate } \\
\text { specific antigen) assay }\end{array}$ & $\begin{array}{l}\text { Anti-androgen activity of } n \text {-butanol } \\
\text { extracts. Gallic acid was the strongest } \\
\text { inhibitor of PSA secretion and showed } \\
\text { the most potent anti-proliferative } \\
\text { activity }\end{array}$ & {$[16]$} \\
\hline $\begin{array}{l}\text { Commercial } E \text {. } \\
\text { angustifolium ethanolic } \\
\text { extract }\end{array}$ & $\begin{array}{l}\text { In vitro; human prostatic epithelial cells (PZ-HPV-7). Cell } \\
\text { proliferation (MTT assay) and cytotoxicity assay (LDH) }\end{array}$ & $\begin{array}{l}\text { Anti-proliferative effect at } \\
\text { concentration } 1900 \mu \mathrm{g} / \mathrm{ml} \text { after } 24 \text { and } \\
48 \mathrm{~h}\end{array}$ & {$[17]$} \\
\hline
\end{tabular}

E. angustifolium, E. rosmarinifolium, $E$. tetragonum aerial parts/ ethanolic extracts/ oenothein B
In vitro; human prostate cells (PZ-HPV-7, LNCaP); human mammary epithelial cells (AG 11132), human astrocytoma cells (1321N1). Cell proliferation assay (flow cytometry); determination of cell viability (trypan blue exclusion assay) and measurement of DNA synthesis
E. angustifolium herb/ methanolic, ethyl acetate, butanolic, chloroform extracts/oenothein B
In vitro; neutral endopeptidase (NEP) and angiotensin converting enzyme (ACE), aminopeptidase (AMP) activity
Anti-proliferative effect on different prostate cells, strongly correlated with oenothein B concentration

Inhibition of metallopeptidases activity. Oenothein B exhibited inhibition of NEP and ACE with $\mathrm{IC}_{50}=20 \mu \mathrm{M}$ and $\mathrm{IC}_{50}=250 \mu \mathrm{M}$, respectively

Inhibition of metallopeptidases and anti-proliferative effect. Flavonoids showed much slighter activity on NEP and human androgen independent prostate cells (PC-3) proliferation assay (Hoechst 33258)

than oenothein B

Inhibition of metallopeptidases and anti-

E. angustifolium herb/ aqueous and methanolic extracts

In vitro; $\mathrm{PC}-3$ cells; $\mathrm{NEP}$ and $\mathrm{ACE}$ activity, cell proliferation assay (Hoechst 33258), cell cytotoxicity proliferative effect. Oenothein B induced NEP activity in dose-dependent manner

Anti-proliferative effect. Epilobium extracts inhibited cell proliferation with $\mathrm{IC}_{50}$ value of $32.2-44.6 \mu \mathrm{g} / \mathrm{ml}$. Oenothein $\mathrm{B}$ was the strongest inhibitor of cell proliferation $\left(\mathrm{IC}_{50}=7.8 \mu \mathrm{M}\right)$
E. angustifolium, E. hirsutum,

E. parviflorum aerial parts/ aqueous extracts/oenothein $\mathrm{B}$, quercetin-3-O-

In vitro; LNCaP cells. PSA assay and arginase activity assay glucuronide, myricetin-3O-rhamnoside, urolithins
Anti-inflammatory effect. Reduced

release of prostaglandins
E. angustifolium, E. hirsutum, E. parviflorum
aerial parts/aqueous extracts

E. angustifolium/aqueous extract

In vivo; carrageen induced rat paw edema, perfused rabbit ear. Release of prostaglandins

E. angustifolium and E. parviflorum her
aqueous extracts

(n)

\section{Apoptotic effect of extracts (from 2.86 to $86.6 \%$ ) by activation of mitochondrial pathway \\ Anti-proliferative effect. Dose- dependent inhibition of growth and proliferation of cells \\ Cytotoxic and genotoxic effect. DNA damages in HepG2 cells. Antioxidant effect MB-231 \\ In vitro; MTT and Comet assay (human hepatocellular carcinoma HepG2 cells). DNA fragmentation assay. Oxygen Radical Absorbance Capacity (ORAC) \\ In vitro; LNCaP cells. PSA assay and arginase activity assay}


Table 1. (continued)

\begin{tabular}{|c|c|c|c|}
\hline $\begin{array}{l}\text { Plant material/extracts/ } \\
\text { tested compounds }\end{array}$ & Experimental model/assays & Effect & References \\
\hline $\begin{array}{l}\text { E. angustifolium leaves/ } \\
\text { aqueous extract/myricetin- } \\
\text { 3-O-glucuronide }\end{array}$ & $\begin{array}{l}\text { In vivo; carrageen induced rat paw edema; perfused rabbit ear. } \\
\text { Release of prostaglandins. }\end{array}$ & $\begin{array}{l}\text { Anti-inflammatory effect of } \\
\text { myricetin-3-O-glucuronide }\end{array}$ & {$[37]$} \\
\hline $\begin{array}{l}\text { E. angustifolium and } E \text {. } \\
\text { parviflorum herbs/aqueous } \\
\text { and alcoholic extracts }\end{array}$ & $\begin{array}{l}\text { In vivo; carrageen or dextran induced rat paw oedema. Release } \\
\text { of prostaglandins }\end{array}$ & $\begin{array}{l}\text { Anti-inflammatory effect } \\
\text { comparable with indomethacin }\end{array}$ & {$[38]$} \\
\hline $\begin{array}{l}\text { E. angustifolium, E. } \\
\text { hirsutum, E. parviflorum } \\
\text { herbs/aqueous extracts/ } \\
\text { oenothein B, quercetin-3- } \\
\text { O-glucuronide, myricetin- } \\
\text { 3-O-rhamnoside }\end{array}$ & $\begin{array}{l}\text { In vitro; human skin fibroblast (NHDFs), human neutrophils. } \\
\text { Lipoxygenase, cyclooxygenase and hyaluronidase assay. Elastase } \\
\text { and myeloperoxidase (MPO) release by human neutrophils. } \\
\text { Evaluation of ROS production by f-MLP (formylmethionyl- } \\
\text { leucyl-phenylalanine) and PMA (phorbol myristate acetate) } \\
\text { stimulated neutrophils }\end{array}$ & $\begin{array}{l}\text { Antioxidant effect. } \mathrm{ROS}\left(\mathrm{IC}_{50}=5\right. \\
\text { and } 25 \mu \mathrm{g} / \mathrm{ml}) \text {. Extract activity was } \\
\text { related with activity of oenothein } \mathrm{B} \text {, } \\
\text { which was the strongest scavenger } \\
\left(\mathrm{IC}_{50}=1 \mu \mathrm{M}\right)\end{array}$ & {$[32]$} \\
\hline $\begin{array}{l}\text { E. angustifolium aerial } \\
\text { parts/commercial water- } \\
\text { soluble extract }\end{array}$ & $\begin{array}{l}\text { 1,1-Diphenyl-2-picrylhydrazyl (DPPH) Radical Scavenging assay, } \\
\text { Iron(III) to Iron (II) Reducing Activity assay, Iron II Chelation } \\
\text { activity assay, Ascorbate-Iron(III)-Catalyzed Phospholipid } \\
\text { Peroxidation, Site-Specific and Non-Site-specific Hydroxyl } \\
\text { Radical-Mediated 2-Deoxy-D-rybose degradation assays }\end{array}$ & $\begin{array}{l}\text { Antioxidant effect correlated } \\
\text { with the highest total polyphenol } \\
\text { content }\end{array}$ & {$[29]$} \\
\hline $\begin{array}{l}\text { E. angustifolium fresh } \\
\text { leaves, stems, and roots } \\
\text { extracted with phosphate } \\
\text { medium (pH=7) }\end{array}$ & $\begin{array}{l}\text { DPPH assay, Ferric Reducing Antioxidant Power (FRAP) assay, } \\
\text { activity of superoxide dismutase, catalase, peroxidase and } \\
\text { reduced glutathione assay }\end{array}$ & $\begin{array}{l}\text { Antioxidant effect. The highest } \\
\text { antioxidant activity was observed } \\
\text { in leaves }\end{array}$ & {$[30]$} \\
\hline $\begin{array}{l}\text { E. angustifolium, E. } \\
\text { parviflorum, E. montanum, } \\
\text { E. tetragonum, E. roseum/ } \\
\text { methanolic extracts }\end{array}$ & $\begin{array}{l}\text { Spectrophotometric method/ABTS assay }\left(2,2^{\prime} \text {-azino-bis( } 3 \text { - }\right. \\
\text { ethylbenzothiazoline-6-sulfonic acid). Extracts concentration: } \\
10-50 \mu \mathrm{g} / \mathrm{ml}\end{array}$ & $\begin{array}{l}\text { Antioxidant activity comparable } \\
\text { with Trolox and ascorbic acid. ( } \mathrm{IC}_{50} \\
\text { value from } 1.71 \text { to } 3.00 \mu \mathrm{g} / \mathrm{ml} \text { ) }\end{array}$ & {$[31]$} \\
\hline $\begin{array}{l}\text { E. angustifolium aerial parts } \\
\text { collected from } 6 \text { different } \\
\text { locations (Lithuania) }\end{array}$ & Online HPLC-DPPH radical scavenging assay & $\begin{array}{l}\text { Antioxidant effect. RSA was } \\
\text { strongly correlated with amount } \\
\text { of oenothein B. Ecotypes of } E \text {. } \\
\text { angustifolium differ in radical } \\
\text { scavenging activity }\end{array}$ & {$[33]$} \\
\hline $\begin{array}{l}\text { E. angustifolium at different } \\
\text { phase of vegetation/ } \\
\text { aqueous and methanolic } \\
\text { extracts }\end{array}$ & DPPH assay & $\begin{array}{l}\text { Antioxidant activity. The highest } \\
\text { radical scavenging activity showed } \\
\text { material collected during massive } \\
\text { blooming }\end{array}$ & {$[34]$} \\
\hline $\begin{array}{l}\text { E. angustifolium aerial } \\
\text { parts/ethanol, ethyl acetate } \\
\text { and petroleum ether } \\
\text { extracts }\end{array}$ & $\begin{array}{l}\text { DPPH, ABTS, FRAP and TBARS (thiobarbituric acid reactive } \\
\text { substances) assay }\end{array}$ & $\begin{array}{l}\text { Antioxidant effect of ethyl acetate } \\
\text { extract. Methyl gallate, quercetin, } \\
\text { and gallic acid were the main } \\
\text { antioxidant constituents }\end{array}$ & {$[35]$} \\
\hline $\begin{array}{l}29 \text { species including } \\
\text { E. angustifolium herb/ } \\
\text { dry extract dissolved in } \\
\text { methanol }\end{array}$ & $\begin{array}{l}\text { Hole-plate and cylinder diffusion methods. Microbial species: } \\
\text { Aspergilus niger, Bacillus subtilis, Candida albicans, Escherichia } \\
\text { coli, Micrococcus luteus, Pseudomonas aeruginosa, Staphylococcus } \\
\text { aureus, and S. epidermidis }\end{array}$ & $\begin{array}{l}\text { Antimicrobial effect against } S \text {. } \\
\text { aureus and } E \text {. coli }\end{array}$ & {$[41]$} \\
\hline
\end{tabular}

E. angustifolium, E. hirsutum, E. palustre, E. tetragonum, $E$ rosmarinifolium aerial parts/ethanolic extracts

Microdilution method. Microbial species: Staphylococcus aureus, Streptococcus pyogenes, S. sanguis, Enterococcus faecalis, Listeria monocytogenes, Klebsiella pneumoniae, Pseudomonas aeruginosa, Schigella flexneri, Salmonella enteritidis, Candida albicans, C. glabrata, C. crusei, Microsporum canis, M. gypseum, Trychophyton rubrum, T. mentagrophytes

Microdilution method. Microbial species: Candida krusei, C. albicans, C. parapsilosis, C. glabrata, C. tropicalis, C. C. albicans, C. parapsilosis, C. glabrata, C. tropicalis,
lusitaniae, Saccharomyces cerevisiae, Cryptococcus, neoformans, Trichophyton tonsurans, T. rubrum, Microsporum canis, Epidermophyton floccosum, Aspergillus fumigatus, A. flavus,

Fusarium solani, Rhizophus sp.

14 species including angustifolium root/aqueous extracts

E. angustifolium whole plant/commercial

Microdilution method. Microbial species: Staphylococcus aureus, Microsporum luteus, Echerichia coli, Psedomonas aeruginosa
Antimicrobial effect. $E$.

angustifolium and E. hirsutum were

most effective against Microsporum

canis $(\mathrm{MIC}=10 \mu \mathrm{g} / \mathrm{ml}$ )

Antifungal effect. The strongest

activity against $C$. glabra and $C$

lusitaniae (MIC $=25$ and $50 \mu \mathrm{g} / \mathrm{ml}$,

respectively)

Antibacterial effect, extracts more

effective than vancomycine or

tetracycline

Antibacterial effect. No

differences between antimicrobial

E. angustifolium leaves

Microdilution and diffusion methods. Microbial species: scherichia coli (including p-fimbriae positive strain), Pseudomonas aeruginosa, Candida albicans, C. tropicalis, $C$ dubliniensis, Saccharomyces cerevisiae, Proteus mirabilis
E. angustifolium aeria parts/1,3-butanediol extract
In vitro; normal human dermal fibroblast. In vivo; skin exposure to UV radiation (8 healthy Caucasian volunteers)
Photoprotective (UV-induced erythema in vivo) and antioxidant effect 
of prostate specific antigen (PSA) secretion and the arginase activity of Epilobium spp. extracts. Aqueous extracts of E. angustifolium, E. parviflorum and E. hirsutum reduced PSA secretion from 325.6 to about $90 \mathrm{ng} / \mathrm{ml}$, and inhibited the arginase activity, which was dependent on the oenothein $\mathrm{B}$ concentration. Oenothein B showed a stronger inhibitory effect on cell proliferation $\left(\mathrm{IC}_{50}=7.8 \mu \mathrm{M}\right.$ ), PSA secretion $\left(\mathrm{IC}_{50}=21.9 \mu \mathrm{M}\right)$ and arginase activity $\left(\mathrm{IC}_{50}=19.2 \mu \mathrm{M}\right)$ compared to the flavonoids $\left(\mathrm{IC}_{50}>40 \mu \mathrm{M}\right.$ for myricetin-3-O-rhamnoside). Despite the lack of oenothein $\mathrm{B}$, biological activity was also determined in the case of acetate extract, especially from E. angustifolium, but this effect was weaker, and attributed to an unidentified extract compound. Additionally, urolithins (metabolites of ellagitannins transformed by gut microbiota) were also tested, and urolithin $\mathrm{C}$ showed the strongest antiproliferative effect $\left(\mathrm{IC}_{50}=35.2 \mu \mathrm{M}\right)$. However, it was weaker than that of oenothein B. The apoptotic potential of the standardized E. angustifolium, E. parviflorum and $E$. hirsutum extracts was demonstrated on LNCaP cells [23]. A significant increase in the level of apoptotic cells compared to the controls (86.6 vs 2.86\%) was observed. All extracts reduced the mitochondrial potential and increased caspase- 3 activity over four-fold ( $0.3 v s 1.26 \mathrm{ng} / \mathrm{mg}$ of protein). The authors also suggested another mode of action via reactive oxygen species (ROS). Cumulative evidence has indicated that oenothein $\mathrm{B}$ can stimulate the ROS production and trigger apoptosis in a caspase-independent manner [24-26]. Cytotoxic and apoptotic effects of E. angustifolium ethanolic extract were investigated and confirmed by MTT and Comet assays [27]. Extracts at concentration of $50-75 \mu \mathrm{g} / \mathrm{ml}$ reduced cell viability and induced DNA damages in hepatocellular carcinoma.

The inhibition of growth and proliferation of some breast cancer cell lines exposed to E. angustifolium extracts was also reported [28]. In turn, antiproliferative activity of fireweed water extract and oenothein B in in vitro and in vivo models was described by Piwowarski et al. [15]. This extract and oenothein B showed a selective effect against cancer cells (LNCaP and PZ-HPV-7), more significantly inhibiting the proliferation of the dihydrotestosterone-stimulated LNCaP cells in comparison with antiandrogens. Recently, in vitro screening of 50 isolated compounds from $n$-butanol and acetate extracts revealed that 26 substances induced anti-proliferation in BPH-1 cells, while 36 of them showed PSA (prostate specific antigen) inhibition in LNCaP cells [16]. Among isolated compounds, gallic acid exhibited the most potent antiproliferative effect in both cell lines.

\section{Antioxidant activity}

Commercially available water-soluble extracts from E. angustifolium leaves showed significant antioxidant activity in in vitro assays [29] (tab. 1). The antioxidant properties of different plant parts (roots, leaves, and stems) were evaluated by Štajner et al. [30]. The highest activity determined by DPPH and FRAP assays was noted for leaves. The strong antioxidant capacity of Epilobium species was attributed to the high ellagitannin content [31] and particularly to oenothein $B[32,33]$. The assessment of radical scavenger activity (RSA) of E. angustifolium harvested during vegetation with respect to the flavonoid content was reported by Maruška et al. [34]. The highest levels of flavonoids (8.71-11.12 mg/g) and RSA were determined for flowers collected during the massive blooming phase. Lipid peroxidation inhibition and antiradical (DPPH, ABTS) activities of ethanolic extracts have been recently confirmed [35]. In these investigations, flavonoids and phenolic acids were the main components of the active fractions of the fireweed extract.

\section{Anti-inflammatory and immunomodulatory activities}

In early studies, the reduction in pro-inflammatory cytokines and inhibition of prostaglandin synthesis $\left(\mathrm{PGE}_{2}, \mathrm{PGI}_{2}, \mathrm{PGD}_{2}\right)$ were revealed in in vivo assays $[36,37]$ (tab. 1). The E. angustifolium extract showed strong anti-inflammatory activity towards carrageenan-induced edema in rats [38]. Additionally, myricetin-3-O-glucuronide isolated from the leaves was more than ten times more effective than the nonsteroidal anti-inflammatory drug - indomethacin. Kiss et al. [32] compared the anti-inflammatory properties of E. parviflorum, E. hirsutum and E. angustifolium extracts as well as selected compounds: oenothein B, quercetin-3-O-glucuronide and myricetin-3-O-rhamnoside in an in vitro assay. All extracts inhibited hyaluronidase and lipoxygenase activity. Oenothein B was the strongest inhibitor of hyaluronidase $\left(\mathrm{IC}_{50}=1.1 \mu \mathrm{M}\right)$ and myeloperoxidase $\left(\mathrm{IC}_{50}=7.7 \mu \mathrm{M}\right)$, whereas flavonoids showed no or a much weaker effect. Oenothein B was also active against cyclooxygenase-1 (COX-1) at a level comparable with indomethacin, while extracts exhibited 
weak activity against both enzymes (COX-1 and COX-2).

Activation of phagocytic cells and modulation of immune function by the E. angustifolium extract and isolated oenothein B were also reported $[24,39,40]$. Fireweed extract activated ROS production in murine bone marrow leukocytes in a dose-dependent manner and induced NF- $\kappa \mathrm{B}$ in human monocytes [24]. Differences in cytokine production by $\mathrm{T}$ cells exposed to oenothein B were observed [40]. The authors suggested that the immunostimulant effect of oenothein $\mathrm{B}$ could be modulated by $\mathrm{T}$ cell age, particularly with respect to the cytokine production.

\section{Antimicrobial activity}

Antimicrobial activity of E. angustifolium extract against Staphylococcus aureus and Escherichia coli was determined by Rauha et al. [41] (tab. 1). In turn, Battinelli et al. [42] reported moderate or weak action of ethanolic extract against both Gram-positive and Gram-negative bacteria as well as yeast. The significant antifungal activity of E. angustifolium root extract against Candida glabrata, C. lusitaniae, and Saccharomyces cerevisiae (MIC $=25-50 \mu \mathrm{g} / \mathrm{ml}$ ) was detected by Webster et al. [43]. Furthermore, the whole plant ethanolic extracts strongly inhibited the growth of Escherichia coli, Micrococcus luteus, Pseudomonas aeruginosa, and Staphylococcus aureus. Obtained extracts were more effective than antibiotics: vancomycin and tetracycline [44]. Kosalec et al. [45] compared the activity of ethanolic extracts from leaves and flowers of $E$. angustifolium, and exhibited their similar effect against various bacterial strains and fungi: Staphylococcus aureus (including methicillin-resistant S. aureus), Bacillus subtilis, Escherichia coli, Pseudomonas aeruginosa, Proteus mirabilis, Candida albicans, C. tropicalis, C. dubliniensis, and Saccharomyces cerevisiae $(\mathrm{MIC}=4.6-18.2 \mathrm{mg} / \mathrm{ml})$.

\section{Other properties}

Analgesic activity of E. angustifolium tincture was determined by the hot plate and writhing test in mice [46] (tab. 1). Additionally, the photoprotective and antiaging properties of fireweed extract have been revealed in human stress-induced fibroblasts in in vitro and in vivo models [47].

\section{Toxicity and safety}

According to the European Medicines Agency (EMA), E. angustifolium extracts did not show toxicity and can be considered safe in traditionally used doses [2]. Nevertheless, there are no clinical data about the safety of $E$. angustifolium extracts, and there are only two in vivo studies $[46,48]$. Tita et al. [46] conducted a single-dose toxicity experiment on mice and determined $\mathrm{LD}_{50}=1.4 \mathrm{~g} / \mathrm{kg}$ bw (subcutaneously) after $24 \mathrm{~h}$. In a repeated-dose toxicity study hydro-alcoholic extracts of $E$. angustifolium, E. hirsutum and E. parviflorum were tested on albino male Wistar rats and no toxicity effect was observed in the brain, hypothalamichypophyso-adrenal axis, liver, kidneys, spleen or thymus [48]. The results of other studies showed the influence of $E$. angustifolium on the expression of cytochromes $[49,50]$ - enzymes that metabolize drugs and could cause the potential risk of interactions.

\section{BIOAVAILABILITY OF ELLAGITANNINS}

Oenothein B is the most abundant ellagitannin of fireweed with a broad spectrum of biological activities, including anti-androgenic, cytotoxic, antioxidant, anti-inflammatory, immunomodulatory, and neuroprotective effects $[6,7]$. However, the bioavailability of ellagitannins is very poor due to the large molecular size and their relatively high polarity. Ellagitannins undergo partial hydrolysis to ellagic acid in gastrointestinal tract and then free ellagic acid and the remaining ellagitannins are metabolized by the colon microbiota to dibenzopyran-6-one derivatives - urolithins $[51,52]$. Transformation of ellagic acid starts from Uro-M5 and then leads to the production of different urolithins and their intermediates, while Uro-A and Uro-B are final catabolic products. The presence of urolithins and their conjugate derivatives has been detected at relatively high concentrations in plasma, urine and feces. Currently, Gordonibacter urolithinfaciens and G. pamelaeae $[53,54]$ as well as Ellagibacter isourolithinifaciens [55] and Bifidobacterium pseudocatenulatum (INIA P815) [56] have been identified as urolithin producers.

Interindividual variability in the qualitative and quantitative urolithins production was revealed in humans $[58,59]$. Three urolithin metabotypes have been classified: metabotype A, B and 0. Metabotype $\mathrm{A}$ is characterized by the excretion of Uro-A 
and its conjugates, metabotype $\mathrm{B}$ produces Uro-B and IsoUro-A in addition to Uro- $A$, and metabotype 0 does not produce Uro-A, IsoUro-A, or Uro-B [60]. The relationship between the presence of Gordonibacter microbes and individuals who were able to produce Uro-A was observed. Moreover, higher amounts of Gordonibacter were found in individuals with metabotype $A$ than in those with metabotype $B$ $[52,60]$. It has been considered that interindividual variability is caused by the differences and composition of the intestinal microbiota. Recently, aging has been reported as the main factor that determines urolithin metabotypes with potential consequences for human health [59].

Urolithins which have shown antiproliferative, anti-inflammatory and anticancer properties differ in their activities depending on their structure $[22,61,62]$. Furthermore, studies on animal models also revealed the protection role of urolithins in neuronal inflammation and their potential benefit effect for Alzheimer's disease [63] and other degenerative diseases [64, 65]. At present, a topical issue is whether the oral application or consumption of ellagitannin-rich dietary products are able to provide appropriate bioactive concentrations in blood, then transport this to target organs. Animal tests exhibited that urolithins are able to reach some organs: the prostate, intestine, colon, liver, kidneys, lungs, and brain [65-67]. The oral administration of ellagitannins or urolithins in humans led to the occurrence of urolithins in plasma [68], colon [69] and prostate $[70,71]$.

Dehydroxylation performed by gut microflora affects the urolithin activity level. Stolarczyk et al. [22] reported the occurrence of urolithins (Uro-C, -A, and -B) in human feces after incubation with an $E$. hirsutum extract with a high oenothein B content (23.5\%). In the same paper, the authors evaluated the antiproliferative activity of both E. hirsutum and E. parviflorum extracts, oenothein $B$ and synthesized urolithins (Uro-A, -B, -C) in an in vitro model on LN$\mathrm{CaP}$ prostate cancer cells. These urolithins were active, although not so strong as oenothein $\mathrm{B}$, which exhibited the strongest inhibition activity $\left(\mathrm{IC}_{50}=7.8 \mu \mathrm{M}\right)$. The inhibition effect of urolithin $\mathrm{C}\left(\mathrm{IC}_{50}=35.2 \mu \mathrm{M}\right)$ was comparable with a synthetic drug (flutamide) used in $\mathrm{BPH}$ and prostate cancer therapies, whereas Uro-B showed the weakest activity.

Metabolic fate of oenothein B is still an open question $[15,58]$. The differences in gut metabolism of ellagitannins present in E. angustifolium extract were recognized in humans and animals [58]. The study revealed that the pure oenothein B is not transformed to urolithins after incubation with human microbiota, in contrary to other ellagitannins. Neither urolithins nor oenothein B were present in feces and urine of rats in the E. angustifolium extract-treated group. However, glucuronides-II phase conjugates were identified: nasutin A and its metabolites. Nasutin A was found previously in rats [72] and other animals, but not in humans. Examination of human urine after ingestion of E. angustifolium infusion exhibited the presence of urolithins conjugates: urolithin A glucuronide (GUA), GUB, GUC, and iso-urolithin A glucuronide (GUiA). Neither oenothein B nor nasutin and its conjugates were detected. When the extract was incubated with human gut microbiota ex vivo, urolithins (Uro-A, Uro-B, and IsoUro-A) were produced. However, incubation with isolated oenothein B did not result in urolithin detection, in contrary to the positive control. These studies may suggest that oenothein $B$ is not prone to degradation by microbiota, but another unknown metabolite is transformed into urolithins or nasutin. Therefore, biological activities of oenothein B and other ellagitannins in in vitro and in vivo assays have to be interpreted with caution and there is a need of the further, detail studies on their bioavailability. Recently, Stanisławska et al. [73, 74] investigated the influence of urolithins on androgen-dependent LN$\mathrm{CaP}$ cells. UroA and UroB exhibited antiproliferative and pro-apoptotic activities in LNCaP cells and had an additive antiproliferative effect with an antiandrogen drug bicalutamide [73]. Additionally, the synergic antiproliferative effect of Uro-A and M4 valerolactone was demonstrated on LNCaP cells [74].

\section{CONCLUSIONS}

E. angustifolium is an important medicinal plant with valuable properties for human health, including anti-androgenic, antiproliferative, cytotoxic, antioxidant, anti-inflammatory, immunomodulatory, and antimicrobial activities. Some studies indicate that fireweed extracts have a positive effect on $\mathrm{BPH}$ and potentially in the prostate cancer chemoprevention. Numerous beneficial effects of this plant have been documented in the in vitro and in vivo tests, but the efficacy of $E$. angustifolium phytotherapy is still poorly investigated in the clinical trials.

Oenothein B is considered to be one of the main bioactive compounds of fireweed. Despite many research focused on the anti-BPH effect of this plant substance, it seems that also other secondary metabolites, which have not been tested and/or isolated 
yet, contribute to the biological activities of $E$. angustifolium. For example, gallic acid has been recently proposed as a candidate for the treatment of BPH. Therefore, extensive and detailed studies are needed, including analyses of chemical constituents, their pharmacological properties and bioavailability.

The bioavailability of ellagitannins is still insufficiently known, but recent investigations on their metabolism in humans suggest that the gut microbiota play a key role and can modulate the therapeutic effects. The experimental results support the use of ellagitannins in the prostate cancer chemoprevention, but caution is advised due to a high variation in the production of urolithins by the individual microbiota. Therefore, a better understanding of the role and action mechanism of gastrointestinal microflora is crucial for effective therapy.

\section{ACKNOWLEDGEMENTS}

This work was funded by the Polish National Centre of Research and Development (grant No. PBS2/ A8/23/2013) and the Polish Ministry of Science and Higher Education (contract number 205710/E-198/ SPUB/2016/1).

Ethical approval: The conducted research is not related to either human or animal use.

Conflict of interest: The authors declare they have no conflict of interest.

\section{REFERENCES}

1. Adamczak A, Dreger M, Seidler-Łożykowska K, Wielgus K. Fireweed (Epilobium angustifolium L.): botany, phytochemistry and traditional uses. A review. Herba Pol 2019; 65(3):51-63. doi: http:// dx.doi.org/10.2478/hepo-2019-0018

2. European Medicines Agency (EMA). Committee on Herbal Medicinal Products. Assessment report on Epilobium angustifolium L. and/or Epilobium parviflorum Schreb., herba. 2015. http:// www.ema.europa.eu/en/documents/herbalsummary/willow-herb-summary-public_en.pdf. Accessed 10 January 2020.

3. Thorpe A, Neal D. Benign prostatic hyperplasia. Lancet 2003; 361:1359-1367. doi: http://dx.doi. org/10.1016/S0140-6736(03)13073-5
4. Allkanjari O, Vitalone A. What do we know about phytotherapy of benign prostatic hyperplasia? Life Sci J 2015; 126:42-56. doi: http://dx.doi. org/10.1016/j.lfs.2015.01.023

5. Granica S, Piwowarski JP, Czerwińska ME, Kiss AK. Phytochemistry, pharmacology and traditional uses of different Epilobium species (Onagraceae): A review. J Ethnopharmacol 2014; 156:316-346. doi: http://dx.doi.org/10.1016/j.jep.2014.08.036

6. Schepetkin IA, Ramstead AG, Kirpotina LN, Voyich JM, Jutila MA, Quinn MT. Therapeutic potential of polyphenols from Epilobium angustifolium (fireweed). Phytother Res 2016; 30(8):1287-1297. doi: http://dx.doi.org/10.1002/ptr.5648

7. Yoshida T, Yoshimura M, Amakura Y. Chemical and biological significance of oenothein $\mathrm{B}$ and related ellagitannin oligomers with macrocyclic structure. Molecules 2018; 23(3):552. doi: http:// dx.doi.org/10.3390/molecules23030552

8. Ismail T, Calcabrini C, Diaz AR, Fimognari C, Turrini E, Cantazaro E et al. Ellagitannins in cancer chemoprevention and therapy. Toxins 2016; 8(5):151. doi: http://dx.doi.org/10.3390/toxins8050151

9. Livingstone TL, Beasy G, Mills RD, Plumb J, Needs PW, Mithen R et al. Plant bioactives and the prevention of prostate cancer: Evidence from human studies. Nutrients 2019; 11(9):2245. doi: http://dx.doi.org/10.3390/nu11092245

10. Selma MV, González-Sarrías A, Salas-Salvadó J, Andrés-Lacueva C, Alasalvar C, Örem A et al. The gut microbiota metabolism of pomegranate or walnut ellagitannins yields two urolithinmetabotypes that correlate with cardiometabolic risk biomarkers: Comparison between normoweight, overweight-obesity and metabolic syndrome. Clin Nutr 2018; 37(3): 897-905. doi: http://dx.doi.org/10.1016/j.clnu.2017.03.012

11. Peyrottes A, Seksik P, Doré J, Marteau P. The microbiome in IBD. In: Sheng Ding N, De Cruz P. (eds.). Biomarkers in inflammatory bowel diseases. Cham. Springer 2019: 293-301.

12. Hiermann A, Bucar F. Studies of Epilobium angustifolium extracts on growth of accessory sexual organs in rats. J Ethnopharmacol 1997; 55:1 79-183. doi: http://dx.doi.org/10.1016/S03788741(96)01498-5 
13. Ducrey B, Marston A, Göhring S, Hartmann RW, Hostettmann K. Inhibition of $5 \alpha$-reductase and aromatase by the ellagitannins oenothein $\mathrm{A}$ and oenothein B from Epilobium species. Planta Med 1997; 63(2):111-114. doi: http://dx.doi. org/10.1055/s-2006-957624

14. Lesuisse D, Berjonneau J, Ciot C, Devaux P, Doucet $B$, Gourvest JF et al. Determination of oenothein $\mathrm{B}$ as the active 5 - $\alpha$-reductase-inhibiting principle of the folk medicine Epilobium parviflorum. J Nat Prod 1996; 59(5):490-492. doi: http://dx.doi. org/10.1021/np960231c

15. Piwowarski JP, Bobrowska-Korczak B, Stanisławska I, Bielecki W, Wrzesień R, Granica S et al. Evaluation of the effect of Epilobium angustifolium aqueous extract on LNCaP cell proliferation in in vitro and in vivo models. Planta Med 2017; 83(14-15):1159-1168. doi: http://dx.doi. org/10.1055/s-0043-109372

16. Deng L, Zong W, Tao X, Liu S, Feng Z, Lin Y et al. Evaluation of the therapeutic effect against benign prostatic hyperplasia and the active constituents from Epilobium angustifolium L. J Ethnopharmacol 2019; 232:1-10. doi: http://dx.doi. org/10.1016/j.jep.2018.11.045

17. Vitalone A, Bordi F, Baldazzi C, Mazzanti G, Saso L, Tita B. Anti-proliferative effect on a prostatic epithelial cell line (PZ-HPV-7) by Epilobium angustifolium L. Farmaco 2001; 56(57):483-489. doi: http://dx.doi.org/10.1016/S0014827X(01)01067-9

18. Vitalone A, McColl J, Thome D, Costa LG, Tita B. Characterization of the effect of Epilobium extracts on human cell proliferation. Pharmacology 2003; 69(2):79-87. doi: http://dx.doi. org/10.1159/000072360

19. Kiss A, Kowalski J, Melzig MF. Compounds from Epilobium angustifolium inhibit the specific metallopeptidases ACE, NEP and APN. Planta Med 2004; 70(10):919-923. doi: http://dx.doi. org/10.1055/s-2004-832617

20. Kiss A, Kowalski J, Melzig MF. Effect of Epilobium angustifolium L. extracts and polyphenols on cell proliferation and neutral endopeptidase activity in selected cell lines. Pharmazie 2006; 61(1):66-69.

21. Kiss A, Kowalski J, Melzig MF. Induction of neutral endopeptidase activity in PC-3 cells by an aqueous extract of Epilobium angustifolium L. and oenothein B. Phytomedicine 2006; 13(4):284-289. doi: http://dx.doi.org/10.1016/j. phymed.2004.08.002

22. Stolarczyk M, Piwowarski JP, Granica S, Stefańska J, Naruszewicz M, Kiss AK. Extracts from Epilobium sp. herbs, their components and gut microbiota metabolites of Epilobium ellagitannins, urolithins, inhibit hormone-dependent prostate cancer cells-(LNCaP) proliferation and PSA secretion. Phytother Res 2013; 27(12):1842-1848. doi: http://dx.doi.org/10.1002/ptr.4941

23. Stolarczyk M, Naruszewicz M, Kiss AK. Extracts from Epilobium sp. herbs induce apoptosis in human hormone-dependent prostate cancer cells by activating the mitochondrial pathways. J Pharm Pharmacol 2013; 65(7):1044-1054. doi: http:// dx.doi.org/10.1111/jphp.12063

24. Schepetkin IA, Kirpotina LN, Jakiw L, Khlebnikov AI, Blaskovich CL, Jutila MA et al. Immunomodulatory activity of oenothein B isolated from Epilobium angustifolium. J Immunol 2009; 183(10):6754-6766. doi: http://dx.doi. org/10.4049/jimmunol.0901827

25. Yoshimura M, Akiyama H, Kondo K, Sakata K, Matsuoka H, Amakura Y et al. Immunological effects of oenothein $\mathrm{B}$, an ellagitannin dimer, on dendritic cells. Int J Mol Sci 2013; 14(1):46-56. doi: http://dx.doi.org/10.3390/ijms14010046

26. Pei X, Xiao J, Wei G, Zhang Y, Lin F, Xiong Z et al. Oenothein B inhibits human non-small cell lung cancer A549 cell proliferation by ROS-mediated $\mathrm{PI} 3 \mathrm{~K} / \mathrm{Akt} / \mathrm{NF}-\kappa \mathrm{B}$ signaling pathway. Chem Biol Interact 2019; 298:112-120. doi: http://dx.doi. org/10.1016/j.cbi.2018.09.021

27. Ostrovska H, Oleshchuk O, Vannini S, Cataldi S, Albi E, Codini $\mathrm{M}$ et al. Epilobium angustifolium L.: A medicinal plant with therapeutic properties. EuroBiotech J 2017; 1(2):126-131. doi: http:// dx.doi.org/10.24190/ISSN2564-615X/2017/02.03

28. Maruška A, Ugenskienė R, Raulinaitytė D, Juozaitytè E, Kaškonienè V, Drevinskas T et al. Analysis of antiproliferative effect of Chamerion angustifolium water extract and its fractions on several breast cancer cell lines. Adv Med Sci 2017; 62(1):158-164. doi: http://dx.doi.org/10.1016/j.advms.2016.08.002 
29. Shikov AN, Poltanov EA, Dorman HJD, Makarov VG, Tikhonov VP, Hiltunen R. Chemical composition and in vitro antioxidant evaluation of commercial water-soluble willow herb (Epilobium angustifolium L.) extracts. J Agric Food Chem 2006; 54(10):3617-3624. doi: http://dx.doi.org/10.1021/ jf052606i

30. Štajner D, Popović BM, Boža P. Evaluation of willow herb's (Epilobium angustofolium L.) antioxidant and radical scavenging capacities. Phytother Res 2007; 21(12):1242-1245. doi: http://dx.doi. org/10.1002/ptr.2244

31. Hevesi TB, Blazics B, Kéry Á. Polyphenol composition and antioxidant capacity of Epilobium species. J Pharm Biomed Anal 2009; 49(1):26-31. doi: http://dx.doi.org/10.1016/j.jpba.2008.09.047

32. Kiss AK, Bazylko A, Filipek A, Granica S, Jaszewska E, Kiarszys U et al. Oenothein B's contribution to the anti-inflammatory and antioxidant activity of Epilobium sp. Phytomedicine 2011; 18(7):557-560. doi: http://dx.doi. org/10.1016/j.phymed.2010.10.016

33. Kaškonienè V, Maruška A, Akuṇeca I, Stankevičius M, Ragažinskienė $\mathrm{O}$, Bartkuvienė V et al. Screening of antioxidant activity and volatile compounds composition of Chamerion angustifolium (L.) Holub ecotypes grown in Lithuania. Nat Prod Res 2016; 30(12):1373-1381. doi: http:// dx.doi.org/10.1080/14786419.2015.1058792

34. Maruška A, Ragažinskienė $O$, Vyšniauskas $O$, Kaškonienė $\mathrm{V}$, Bartkuvienė $\mathrm{V}$, Kornyšova $\mathrm{O}$ et al. Flavonoids of willow herb (Chamerion angustifolium (L.) Holub) and their radical scavenging activity during vegetation. Adv Med Sci 2014; 59(1):136-141. doi: http://dx.doi.org/10.1016/j. advms.2013.10.002

35. Deng LQ, Zhou SY, Mao JX, Liu S, Lan XZ, Liao $\mathrm{ZH}$ et al. HPLC-ESI-MS/MS analysis of phenolics and in vitro antioxidant activity of Epilobium angustifolium L. Nat Prod Res 2018; 32(12):14321435. doi: http://dx.doi.org/10.1080/14786419.20 17.1344659

36. Hiermann A, Juan H, Sametz W. Influence of Epilobium extracts on prostaglandin biosynthesis and carrageenin induced oedema of the rat paw. J Ethnopharmacol 1986; 17:161-169. doi: http:// dx.doi.org/10.1016/0378-8741(86)90055-3
37. Hiermann A, Reidlinger M, Juan H, Sametz W. Isolierung des antiphlogistischen Wirkprinzips von Epilobium angustifolium. [Isolation of the antiphlogistic active principle from Epilobium angustifolium] Planta Med 1991; 57(4):357-360. doi: http://dx.doi.org/10.1055/s-2006-960117

38. Juan H, Sametz W, Hiermann A. Anti-inflammatory effects of a substance extracted from Epilobium angustifolium. Agents Actions 1988; 23(1-2):106-107.

39. Ramstead AG, Schepetkin IA, Quinn MT, Jutila MA. Oenothein B, a cyclic dimeric ellagitannin isolated from Epilobium angustifolium, enhances IFN $\gamma$ production by lymphocytes. PLoS ONE 2012; 7(11):e50546. doi: http://dx.doi. org/10.1371\%2Fjournal.pone.0050546

40. Ramstead AG, Schepetkin IA, Todd K, Loeffelholz J, Berardinelli JG, Quinn MT et al. Aging influences the response of $\mathrm{T}$ cells to stimulation by the ellagitannin, oenothein B. Int Immunopharmacol 2015; 26(2):367-377. doi: http://dx.doi. org/10.1016/j.intimp.2015.04.008

41. Rauha JP, Remes S, Heinonen M, Hopia A, Kähkönen M, Kujala T et al. Antimicrobial effects of Finnish plant extracts containing flavonoids and other phenolic compounds. Int J Food Microbiol 2000; 56(1):3-12. doi: http://dx.doi.org/10.1016/ S0168-1605(00)00218-X

42. Battinelli L, Tita B, Evandri MG, Mazzanti G. Antimicrobial activity of Epilobium spp. extracts. Farmaco 2001; 56(5-7):345-348. doi: http:// dx.doi.org/10.1016/S0014-827X(01)01047-3

43. Webster D, Taschereau P, Belland RJ. Antifungal activity of medicinal plant extracts; preliminary screening studies. J Ethnopharmacol 2008; 115:140-146. doi: http://dx.doi.org/10.1016/j. jep.2007.09.014

44. Bartfay WJ, Bartfay E, Johnson JG. Gram-negative and Gram-positive antibacterial properties of the whole plant extract of willow herb (Epilobium angustifolium). Biol Res Nurs 2012; 14(1):85-89. doi: http://dx.doi.org/10.1177/1099800410393947

45. Kosalec I, Kopjar N, Kremer D. Antimicrobial activity of willowherb (Epilobium angustifolium L.) leaves and flowers. Curr Drug Targets 2013; 14(9):986-991. doi: http://dx.doi.org/10.2174/138 94501113149990177 
46. Tita B, Abdel-Haq H, Vitalone A, Mazzanti G, Saso L. Analgesic properties of Epilobium angustifolium, evaluated by the hot plate test and the writhing test. Farmaco 2001; 56(5-7):341-343. doi: http://dx.doi. org/10.1016/S0014-827X(01)01046-1

47. Ruszová E, Cheel J, Pávek S, Moravcová M, Hermannová $\mathrm{M}$, Matějková I et al. Epilobium angustifolium extract demonstrates multiple effects on dermal fibroblasts in vitro and skin photo-protection in vivo. Gen Physiol Biophys 2013; 32(3):347359. doi: http://dx.doi.org/10.4149/gpb_2013031

48. Roman I, Rusu MA, Puică C, Borşa M. Citotoxic effects of three species of Epilobium (Onagraceae) herbal extracts in rats. Studia Univ Vasile Goldiş Seria ŞtiințeleVieții 2010; 20(1):19-23.

49. Kujawski R, Ożarowski M, Derebecka-Hołysz N, Bartkowiak-Wieczorek J, Bogacz A, Karasiewicz $\mathrm{M}$ et al. Effect of willow herb (Epilobium angustifolium L.) extract on gene expression of selected P450 cytochromes in rat liver - preliminary study. Herba Pol 2009; 55(4):52-64.

50. Kujawski R, Mrozikiewicz PM, Mikołajczak P€, Kuzio G, Bogacz A, Cichocka J et al. Influence of Epilobium angustifolium and Serenoa repens extracts on cytochrome 2D2 and 3A1 expression level in rats. Herba Pol 2010; 56(4):39-51.

51. Bialonska D, Ramnani P, Kasimsetty SG, Muntha KR, Gibson GR, Ferreira D. The influence of pomegranate by-product and punicalagins on selected groups of human intestinal microbiota. Int J Food Microbiol 2010; 140(2-3):175182. doi: http://dx.doi.org/10.1016/j.ijfoodmicro.2010.03.038

52. Tomás-Barberán FA, González-Sarrías A, García-Villalba R, Núñez-Sánchez MA, Selma MV, García-Conesa MT et al. Urolithins, the rescue of "old" metabolites to understand a "new" concept: Metabotypes as a nexus among phenolic metabolism, microbiota dysbiosis, and host health status. Mol Nutr Food Res 2017; 61(1):1500901. doi: http://dx.doi.org/10.1002/mnfr.201500901

53. Selma MV, Beltrán D, García-Villalba R, Espín JC, Tomás-Barberán FA. Description of urolithin production capacity from ellagic acid of two human intestinal Gordonibacter species. Food Funct 2014; 5(8):1779-1784. doi: http://dx.doi. org/10.1039/c4fo00092g
54. Selma MV, Tomás-Barberán FA, Beltrán D, García-Villalba R, Espín JC. Gordonibacter urolithinfaciens sp. nov., a urolithin-producing bacterium isolated from the human gut. Int J Syst Evol Microbiol 2014; 64:2346-2352. doi: http://dx.doi. org/10.1099/ijs.0.055095-0

55. Beltrán D, Romo-Vaquero M, Espín JC, Tomás-Barberán FA, Selma MV. Ellagibacter isourolithinifaciens gen. nov., sp. nov., a new member of the family Eggerthellaceae, isolated from human gut. Int J Syst Evol Microbiol 2018; 68(5):1707-1712. doi: http://dx.doi.org/10.1099/ ijsem.0.002735

56. Gaya P, Peirotén Á, Medina M, Álvarez I, Landete JM. Bifidobacterium pseudocatenulatum INIA P815: The first bacterium able to produce urolithins A and B from ellagic acid. J Funct Foods 2018; 45:95-99. doi: http://dx.doi.org/10.1016/j. jff.2018.03.040

57. Romo-Vaquero M, García-Villalba R, GonzálezSarrías A, Beltrán D, Tomás-Barberán FA, Espín $\mathrm{CA}$ et al. Interindividual variability in the human metabolism of ellagic acid: Contribution of Gordonibacter to urolithin production. J Funct Foods 2015; 17:785-791. doi: http://dx.doi. org/10.1016/j.jff.2015.06.040

58. Piwowarski JP, Granica S, Stefańska J, Kiss AK. Differences in metabolism of ellagitannins by human gut microbiota ex vivo cultures. J Nat Prod 2016; 79(12):3022-3030. doi: http://dx.doi. org/10.1055/s-0043-109372

59. Cortés-Martín A, García-Villalba R, GonzálezSarrías A, Romo-Vaquero M, Loria-Kohen V, Ramírez-de-Molina A et al. The gut microbiota urolithin metabotypes revisited: the human metabolism of ellagic acid is mainly determined by aging. Food Funct 2018; 9(8):4100-4106. doi: http://dx.doi.org/10.1039/c8fo00956b

60. Tomás-Barberán FA, Selma MV, Espín JC. Interactions of gut microbiota with dietary polyphenols and consequences to human health. Curr Opin Clin Nutr Metab Care 2016; 19(6):471-476. doi: http://dx.doi.org/10.1097/ MCO.0000000000000314

61. Piwowarski JP, Granica S, Zwierzyńska M, Stefańska J, Schopohl P, Melzig MF et al. Role of human gut microbiota metabolism in the anti-in- 
flammatory effect of traditionally used ellagitannin-rich plant materials. J Ethnopharmacol 2014; 155:801-809. doi: http://dx.doi.org/10.1016/j. jep.2014.06.032

62. Sánchez González C, Ciudad CJ, Izquierdo Pulido M, Noé V. Urolithin A causes p21 up regulation in prostate cancer cells. Eur J Nutr 2016; 55(3):1099-1112. doi: http://dx.doi.org/10.1007/ s00394-015-0924-Z

63. Yuan T, Ma H, Liu W, Niesen DB, Shah N, Crews $\mathrm{R}$ et al. Pomegranate's neuroprotective effects against Alzheimer's disease are mediated by urolithins, its ellagitannin-gut microbial derived metabolites. ACS Chem Neurosci 2016; 7(1):26-33. doi: http://dx.doi.org/10.1021/ acschemneuro.5b00260

64. Ryu D, Mouchiroud L, Andreux PA, Katsyuba E, Moullan N, Nicolet-dit-Félix AA et al. Urolithin A induces mitophagy and prolongs lifespan in $C$. elegans and increases muscle function in rodents. Nat Med 2016; 22:879-888. doi: http://dx.doi. org/10.1038/nm.4132

65. Kujawska M, Jourdes M, Kurpik M, Szulc M, Szaefer H, Chmielarz P et al. Neuroprotective effects of pomegranate juice against Parkinson's disease and presence of ellagitannins-derived metabolite - Urolithin A - in the brain. Int J Mol Sci 2020; 21(1):202. doi: http://dx.doi.org/10.3390/ ijms 21010202

66. Cerda B, Ceron JJ, Tomás-Barberán FA, Espín JC. Repeated oral administration of high doses of the pomegranate ellagitannin punicalagin to rats for 37 days is not toxic. J Agric Food Chem 2003; 51(11):3493-3501. doi: http://dx.doi.org/10.1021/ jf020842c

67. Seeram NP, Aronson WJ, Zhang Y, Henning SM, Moro A, Lee RP et al. Pomegranate ellagitannin-derived metabolites inhibit prostate cancer growth and localize to the mouse prostate gland. J Agric Food Chem 2007; 55(19):7732-7737. doi: http://dx.doi.org/10.1021/jf071303g

68. Seeram NP, Zhang Y, McKeever R, Henning SM, Lee RP, Suchard MA et al. Pomegranate juice and extracts provide similar levels of plasma and urinary ellagitannin metabolites in human subjects. J Med Food 2008; 11(2):390-394. doi: http:// dx.doi.org/10.1089\%2Fjmf.2007.650
69. Núñez-Sánchez MA, García-Villalba R, Monedero-Saiz T, García-Talavera NV, Gómez-Sánchez MB, Sánchez-Álvarez C et al. Targeted metabolic profiling of pomegranate polyphenols and urolithins in plasma, urine and colon tissues from colorectal cancer patients. Mol Nutr Food Res 2014; 58(6):1199-1211. doi: http://dx.doi. org/10.1002/mnfr.201300931

70. González-Sarrías A, Giménez-Bastida JA, García-Conesa MT, Gómez-Sánchez MB, GarcíaTalavera NV, Gil-Izquierdo A et al. Occurrence of urolithins, gut microbiota ellagic acid metabolites and proliferation markers expression response in the human prostate gland upon consumption of walnuts and pomegranate juice. Mol Nutr Food Res 2010; 54(3):311-322. doi: http://dx.doi. org/10.1002/mnfr.200900152

71. Freedland SJ, Carducci M, Kroeger N, Partin A, Rao JY, Jin $Y$ et al. A double-blind, randomized, neoadjuvant study of the tissue effects of POMx pills in men prostate cancer before radical prostatectomy. Cancer Prev Res 2013; 6(10):1120-1127. doi: http://dx.doi.org/10.1158\%2F1940-6207. CAPR-12-0423

72. Kosmala Z, Zduńczyk J, Juśkiewicz A, Jurgoński E, Karlińska E, Macierzyński J et al. Chemical composition of defatted strawberry and raspberry seeds and the effect of these dietary ingredients on polyphenol metabolites, intestinal function, and selected serum parameters in rats. J Agric Food Chem 2015; 63(11):2989-2996. doi: http:// dx.doi.org/10.1021/acs.jafc.5b00648

73. Stanisławska IJ, Piwowarski JP, Granica S, Kiss AK. The effects of urolithins on the response of prostate cancer cells to non-steroidal antiandrogen bicalutamide. Phytomedicine 2018; 46:176-183. doi: http://dx.doi.org/10.1016/j. phymed.2018.03.054

74. Stanisławska IJ, Granica S, Piwowarski JP, Szawkało J, Wiązecki K, Czarnocki Z et al. The activity of urolithin A and M4 valerolactone, colonic microbiota metabolites of polyphenols, in a prostate cancer in vitro model. Planta Med 2019; 85(2):118-125. doi: http://dx.doi. org/10.1055/a-0755-7715 